\title{
Cannabinoid Receptor 2 Signaling in Neurodegenerative Disorders: From Pathogenesis to a Promising Therapeutic Target
}

\author{
Tommaso Cassano ${ }^{1 *}$, Silvio Calcagnini ${ }^{2}$, Lorenzo Pace ${ }^{1}$, Federico De Marco ${ }^{3}$, \\ Adele Romano ${ }^{2}$ and Silvana Gaetani ${ }^{2}$ \\ ${ }^{1}$ Department of Clinical and Experimental Medicine, University of Foggia, Foggia, Italy, ${ }^{2}$ Department of Physiology and \\ Pharmacology, Sapienza University of Rome, Rome, Italy, ${ }^{3}$ Laboratory of Virology, The Regina Elena National Cancer \\ Institute, IRCCS, Rome, Italy
}

As a consequence of an increasingly aging population, the number of people affected by neurodegenerative disorders, such as Alzheimer's disease, Parkinson's disease and Huntington's disease, is rapidly increasing. Although the etiology of these diseases has not been completely defined, common molecular mechanisms including neuroinflammation, excitotoxicity and mitochondrial dysfunction have been confirmed and can be targeted therapeutically. Moreover, recent studies have shown that endogenous cannabinoid signaling plays a number of modulatory roles throughout the central nervous system (CNS), including the neuroinflammation and neurogenesis. In particular, the up-regulation of type-2 cannabinoid (CB2) receptors has been found in a number of neurodegenerative disorders. Thus, the modulation of $\mathrm{CB} 2$ receptor signaling may represent a promising therapeutic target with minimal psychotropic effects that can be used to modulate endocannabinoid-based therapeutic approaches and to reduce neuronal degeneration. For these reasons this review will focus on the CB2 receptor as a promising pharmacological target in a number of neurodegenerative diseases.

Keywords: Alzheimer's disease, Parkinson's disease, neuroprotection, neuroinflammation, microglia, astrocytes

\section{INTRODUCTION}

The field of cannabinoid (CB) research has flourished over the past decade and has brought to light diverse functions of the CB system in normal and pathological conditions (D'Addario et al., 2014; Bonnet and Marchalant, 2015). In fact, several studies have demonstrated that endocannabinoid (eCB) system plays significant roles in many biological processes, including neurogenesis, synaptic plasticity, emotional regulation and stress responsiveness (Lu and Mackie, 2015).

The eCB system consists of eCBs, cannabinoid receptors and enzymes involved in the synthesis and degradation of endogenous ligands (Lu and Mackie, 2015).

The eCBs are endogenous lipids that engage $\mathrm{CB}$ receptors, affecting behavior in a fashion that at least partially recapitulates the effects produced by the psychoactive components of cannabis, most notably (2)-trans- $\Delta$ 9-tetrahydrocannabinol (THC) (Mechoulam and Gaoni, 1965; Mechoulam, 1970). The two best-characterized eCBs are $\mathrm{N}$-arachidonoylethanolamide (anandamide, AEA) (Devane et al., 1992) and 2-arachidonoylglycerol (2-AG) (Mechoulam et al., 1995; Sugiura et al., 1995). Both eCBs are synthetized at the post-synaptic terminal from membrane lipid precursors 
in response to high intracellular calcium concentration (Howlett et al., 2002). Thus, eCBs act as retrograde messengers to depress transmitter release from presynaptic terminals (Freund et al., 2003; Fagan and Campbell, 2014).

AEA and 2-AG possess specific pharmacological properties, are engaged in different forms of synaptic plasticity and modulate different behavioral functions (Mechoulam and Parker, 2013).

The CB type 1 (CB1) and type 2 (CB2) receptors are coupled to G-protein, and their signal transduction is mediated by the inhibition of adenylyl cyclases and voltage-gated calcium channels (e.g., N-type, P/Q-type and L-type calcium currents), and by the activation of mitogen-activated protein kinases (MAPK) and inwardly rectifying potassium channels (Howlett et al., 2002; Lu and Mackie, 2015). AEA is a high affinity, CB1selective partial agonist, whereas $2-\mathrm{AG}$ is a moderate affinity, CB1/CB2 full agonist (Sugiura et al., 2000). AEA activates also peroxisome proliferator-activated receptors-alpha and transient receptor potential vannilloid-1 channels (Maccarrone et al., 2010). In humans, CB1 is localized preferentially in the terminals of central and peripheral neurons and glial cells, where it regulates neurotransmitter release and psychoactivity (Egertová et al., 2003; Sánchez and García-Merino, 2012). As far as peripheral tissues, $\mathrm{CB} 1$ is also expressed in heart, uterus, testis, liver and small intestine, as well as in immune cells (Maccarrone et al., 2001; Nong et al., 2001; Klein et al., 2003) and adipose tissue (Spoto et al., 2006).

CB2 was dubbed the "peripheral cannabinoid receptor" as a result of in situ hybridization study that showed high CB2 mRNA expression in spleen, whereas no expression was observed in the brain (Shire et al., 1996; Griffin et al., 2000; Brown et al., 2002). Besides the cells of the immune and hematopoietic systems (e.g., leukocytes, spleen and tonsils), CB2 receptors were found also in other peripheral organs, such as muscle, liver, intestine and testis (Liu et al., 2009). However, CB2 receptor can be also detected in the central nervous system (CNS) (albeit at a lower expression level than CB1receptors) (Núñez et al., 2004; Van Sickle et al., 2005), where its expression is significantly increased following a number of stressful conditions (Viscomi et al., 2009). In particular, CB2 receptor expression is found in neurons within the brainstem, microglia and astrocytes only after specific insults (e.g., neuroinflammation), whereas it cannot be detected in resting microglia (Van Sickle et al., 2005; Núñez et al., 2008; Cabral and Griffin-Thomas, 2009).

In the last decade, increasing evidence has shown that $\mathrm{CB}$ receptors may act as $\mathrm{CB} 1-\mathrm{CB} 2$ receptor heteromers in the brain (Callén et al., 2012). In fact, the expression of CB1-CB2 receptor heteromers was determined in a variety of brain regions, such as the nucleus accumbens, pineal gland and globus pallidus (Callén et al., 2012). Due to this tight functional interaction between $\mathrm{CB}$ receptors, the response to molecules acting as agonists or antagonists may be different when a $\mathrm{CB}$ receptor is engaged in heteroreceptor complexes. Although the clinical relevance of this phenomenon is not entirely clear, additional studies are needed in order to shed further light on this important functional interaction.

eCBs after their actions are rapidly eliminated by cellular uptake and enzymatic hydrolysis. To this regard, AEA is mainly inactivated by fatty acid amide hydrolase (FAAH) (Cravatt et al., 1996; Dinh et al., 2002), whereas 2-AG is predominantly catalyzed by monoacylglycerol lipase (Dinh et al., 2002).

As previously reported, CB1 receptor expression is abundant in the CNS, where it seems to mediate the psychoactive effects of cannabis (Mackie, 2005). Therefore, the scarcity of CNS CB2 receptors makes $\mathrm{CB} 2$ selective drugs attractive as therapeutics as they would presumably invoke minimal psychoactive responses. In support of this hypothesis, CB2 knockout mice demonstrated typical behavioral responses to THC but lost their normal immune responsiveness to THC (Buckley et al., 2000). CB2 levels are also increased under certain conditions and disease states further adding to its attractiveness as a potential therapeutic target (Zhang et al., 2003; Wotherspoon et al., 2005; Yiangou et al., 2006).

Therefore, we will review the role of eCB system in two chronic neurodegenerative diseases, in which the neuroprotective effects following $\mathrm{CB}$ receptors modulation have been reported in different studies. Specifically, we will focus on the role of $\mathrm{CB} 2$ receptors and their agonists, as potential therapeutical targets in Alzheimer's disease (AD) and Parkinson's disease (PD).

\section{ROLE OF CB2 RECEPTOR IN THE NEURODEGENERATION AND NEUROPROTECTION}

Recently, much research has paid attention to the neuroprotective effects of compounds targeting the eCB system. In particular, these studies have focused on identifying molecular targets within the eCB system that may lead to neuroprotection against the most prevalent neurodegenerative disorders (Fernández-Ruiz et al., 2010, 2015).

One of the most important features of $\mathrm{CBs}$ as potential neuroprotectants is their broad-spectrum of activity. This aspect is particularly important in neurodegenerative diseases since declines in neural function are likely due to the concerted involvement of different insults including protein misfolding, neuroinflammation, excitotoxicity, oxidative stress and mitochondrial dysfunction (Serviddio et al., 2011; Cassano et al., 2012, 2016; Aureli et al., 2014). All these pathological processes appear to be modulated by the eCB signaling system. In fact, during aging and neuroinflammation (or when both are present together) there is a widespread disruption of brain tissue homeostasis that involves $\mathrm{eCB}$ signaling, and this contributes to specific dysfunctions in cell function.

Although the CNS is considered a relatively immuneprivileged tissue, it is able to initiate an endogenous immune response. To this regard, astrocytes and microglia are the main innate immune response effectors in brain parenchyma (Halliday and Stevens, 2011).

The most extensively studied mechanism of neuroprotection includes the anti-inflammatory effects of the $\mathrm{CB} 2$ receptors, in which $\mathrm{CB} 2$ protects the brain by restraining inflammatory processes (Benito et al., 2008; Cabral and Griffin-Thomas, 2009). In particular, $\mathrm{CB} 2$ receptor activation modulates the release of 
cytokines, protein molecules responsible for the regulation of immune function and inflammatory responses (Mecha et al., 2016; Turcotte et al., 2016). Differently, the CB1 receptor has been implicated in protection against cell death induced by an overstimulation of excitatory receptors and concurrent calcium release, also known as excitotoxicity (Vendel and de Lange, 2014). CB receptors, therefore, may have an impact on neurodegenerative diseases through two main ways, restraining exitotoxic and immunological processes (Di Iorio et al., 2013).

Moreover, it has been demonstrated that changes in the expression of $\mathrm{CB}$ receptors may be time-dependent and could occur both in the brain and peripheral tissues at different stages of the neurodegenerative process (Bedse et al., 2014, 2015; Di Marzo et al., 2015). For this reason, targeting the CB receptors for therapeutic benefit needs more caution. To this regard, CB1 activity was higher at earlier AD stages in limited hippocampal areas and internal layers of the frontal cortex, but a decrease was observed during the advanced stages (Lastres-Becker et al., 2001; Manuel et al., 2014; Rodríguez-Cueto et al., 2014). The increased $\mathrm{CB} 1$ receptor activity during the initial stages of $\mathrm{AD}$ may indicate neuroprotective action mediated by eCBs in response to initial neuronal damage.

However, CB1 receptors are not usually considered as realistic targets for neuroprotection, because during neurodegenerative processes it has been described a progressive loss of specific populations of neurons that express CB1 receptors (Ramírez et al., 2005; Solas et al., 2013). In line with these results, our group (Bedse et al., 2014), but also Kalifa et al. (2011) reported a decrease in $\mathrm{CB} 1$ protein expression in transgenic mice models of $\mathrm{AD}$.

In contrast, $\mathrm{CB} 2$ receptors are generally less expressed in the neurons of healthy brains, but their expression increases dramatically in reactive microglia and activated astrocytes during neuroinflammation (Stella, 2010; Di Marzo et al., 2015; Fernández-Ruiz et al., 2015). Therefore, the CB2 receptors have the potential to restrain the inflammatory processes that contribute to the declines in neural function occurring in a number of neurodegenerative disorders.

\section{CB2 RECEPTORS AND ALZHEIMER'S DISEASE}

$\mathrm{AD}$ is a devastating neurodegenerative disease leading to progressive cognitive dysfunction. The iconic hallmarks of $\mathrm{AD}$ are $A \beta$ plaques, neurofibrillary tangles (NFTs) and a deficiency in cholinergic neurotransmission. It is widely accepted that the deposition of $\mathrm{A} \beta$ initiates an inflammatory process leading to neurodegeneration (McGeer et al., 2000; Walsh and Selkoe, 2004). Microglial cells are the resident CNS phagocytes of the immune system that mediate inflammatory responses to pathogens and injury by inducing release of pro-inflammatory cytokines including interleukin (IL)- $1 \beta$, IL- 6 , and tumor necrosis factor- $\alpha$ (TNF- $\alpha)$. IL- $1 \beta$ and TNF- $\alpha$ are considered as primary cytokines responsible for chronic inflammation in AD (Sastre et al., 2006). Microglia-derived pro-inflammatory cytokines, in turn, aggravate and propagate inflammation throughout the brain. In fact, IL-1 $\beta$ released from microglia can induce the upregulation of nuclear factor-kappa B (NFкB), MAPK, and Jun-N-terminal kinase (JNK) signaling in neurons and astrocytes, leading to increased inflammatory process and tau phosphorylation, respectively (Sastre et al., 2006; Munoz and Ammit, 2010). Additionally, $\mathrm{A} \beta$ oligomers can induce production of inducible nitric oxide synthase (iNOS), nitric oxide (NO), and TNF- $\alpha$ in astrocytes (White et al., 2005). NO secreted from astrocytes induces abnormal tau hyperphosphorylation in neurons, which prompts an accumulation of NFTs in axons, leading to a disruption of synaptic plasticity and neuronal death (Duan et al., 2012). Moreover, the activation of toll-like receptors (TLR; e.g., TLR-4), involved in pathogen recognition and activation of innate immunity, can also activate the MAPK and NFKB pathways, as well as members of the caspase family responsible for hyperphosphorylation of tau (Churcher, 2006; Reed-Geaghan et al., 2009; Rohn, 2010; Arroyo et al., 2011). Activation of these signaling cascades in neurons could further inhibit synaptic plasticity.

Support for the involvement of the CB2 receptors in $\mathrm{AD}$ pathology is provided by a number of preclinical and human studies. In particular, post-mortem brains from patients with $\mathrm{AD}$ have shown that $\mathrm{CB} 2$ receptors are upregulated in cells that are associated with $\mathrm{A} \beta$-enriched neuritic plaques (Benito et al., 2003; Ramírez et al., 2005; Grünblatt et al., 2009; Halleskog et al., 2011; Mulder et al., 2011; Solas et al., 2013). Apart from human studies, transgenic models of $\mathrm{AD}$ have also revealed overexpression of $\mathrm{CB} 2$ receptors in brain areas affected by $\mathrm{AD}$-pathology (Horti et al., 2010). Increased CB2 mRNA in peripheral blood has been suggested as a peripheral biomarker for the early diagnosis of $\mathrm{AD}$ (Grünblatt et al., 2009). Moreover, an increase in CB2 receptors was also observed in rats and C6 astroglioma cells pre-treated with $\mathrm{A} \beta 42$ (Esposito et al., 2007).

All these effects may be counteracted by the activation of $\mathrm{CB} 2$ receptors, and mechanistic insights of the beneficial effects provided by $\mathrm{CB} 2$ receptor stimulation in $\mathrm{AD}$ has been provided (Ehrhart et al., 2005; Ramírez et al., 2005; Sheng et al., 2005; Chen et al., 2010; Fakhfouri et al., 2012; MartinMoreno et al., 2012) (Table 1). In particular, the CB2 agonist, JWH-015, significantly attenuated CD40-mediated inhibition of microglial phagocytosis of $\mathrm{A} \beta 42$ by interfering with the Janus kinase/Signal transducer and activator of transcription 1 (JAK/STAT1) pathway (Benveniste et al., 2004; Ehrhart et al., 2005). Interestingly, CP55940 (CB1/CB2 full agonist) and JWH015 treatment significantly reduced the interferon-gamma- (IFN$\gamma$ )-induced CD40 expression in microglial cells (Ehrhart et al., 2005).

Ramírez and colleagues demonstrated the effects of $\mathrm{CB}$ receptor agonists on microglial activation (Ramírez et al., 2005). Authors studied in vitro the effects of WIN55,212-2, the mixed CB1/CB2 agonist devoid of antioxidant properties (Howlett et al., 2002; Marsicano et al., 2002), HU-210 and JWH-133, respectively $\mathrm{CB} 1$ and $\mathrm{CB} 2$ selective agonist, in $\mathrm{A} \beta$ induced microglial cells (Ramírez et al., 2005). As expected, $\mathrm{A} \beta$ peptide activated microglial cells and this was associated with increased mitochondrial activity, TNF- $\alpha$ release, cellular morphological changes and secretion of pro-inflammatory 
TABLE 1 | CB2 receptor agonists and their beneficial effects in neurodegenerative diseases (AD and PD).

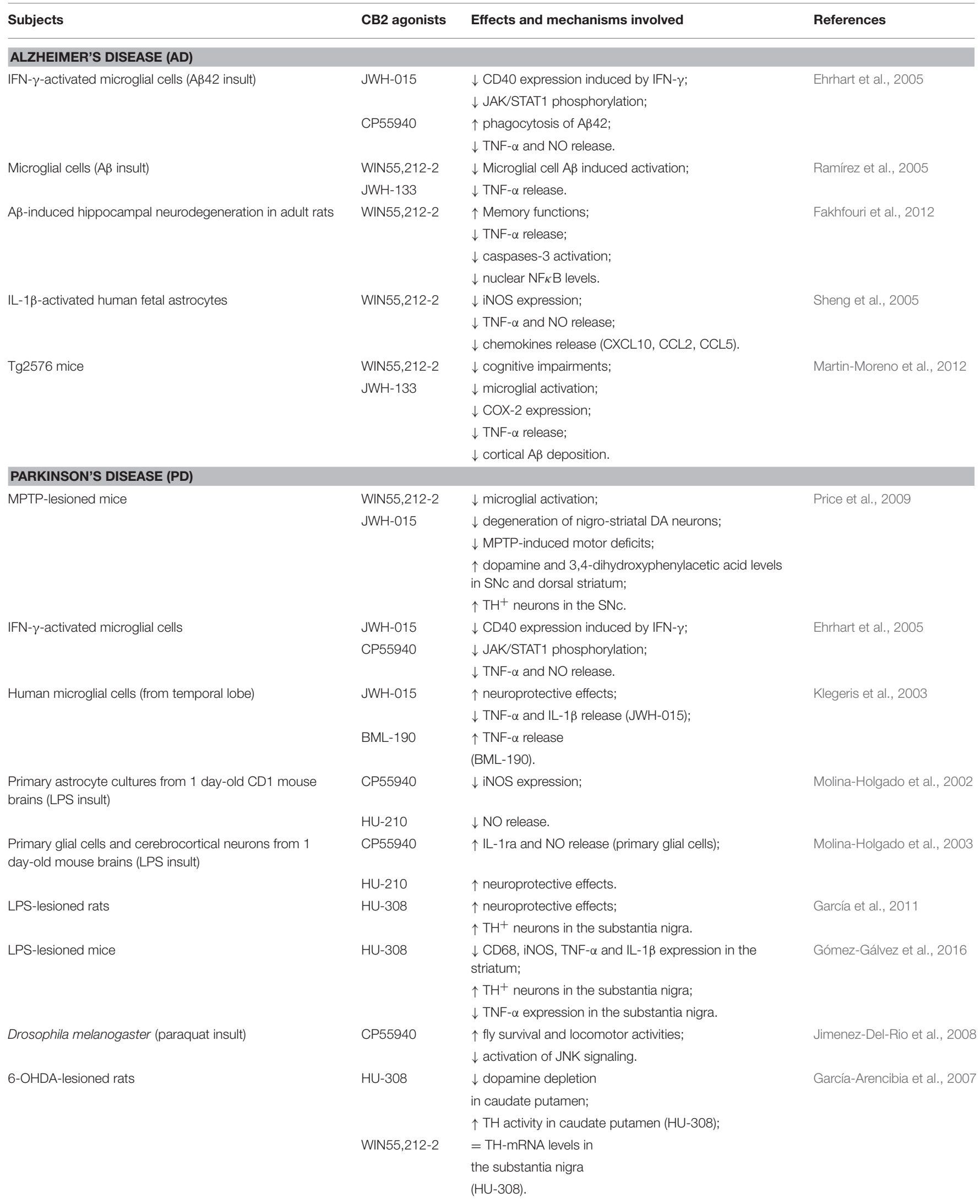

IL-1ra, endogenous IL-1 receptor antagonist. 
cytokines. Cannabinoid treatments prevented the enhancement of TNF- $\alpha$ release and counteracted $A \beta$-mediated activation of microglia (Ramírez et al., 2005).

The protective properties of WIN55,212-2 were also demonstrated in $\mathrm{A} \beta$-induced neurodegeneration in rat hippocampus. WIN55,212-2 significantly improved memory functions and decreased the elevated levels of neuroinflammatory markers like TNF- $\alpha$, activated caspase-3, and nuclear NFKB. The use of antagonists confirmed that these neuroprotective effects of WIN55,212-2 were partially mediated by CB1 and CB2 receptors (Fakhfouri et al., 2012). Moreover, WIN55,212-2, through CB2 receptors, inhibited iNOS and NO production, the release of chemokines (CXCL10, CCL2, and CCL5) and TNF- $\alpha$ from IL-1 $\beta$-activated human fetal astrocytes (Sheng et al., 2005). The CB1 and CB2 receptor-specific antagonists SR141716A (Micale et al., 2013) and SR144528 (Saito et al., 2010), respectively, partially blocked this suppressive effect, which suggests the involvement of both receptors (Sheng et al., 2005).

Furthermore, the effects of cannabinoids were studied in transgenic murine models of $\mathrm{AD}$ treated chronically with WIN55,212-2 or JWH-133, a potent selective CB2 receptor agonist (Martin-Moreno et al., 2012). JWH-133 was able to reduce cognitive impairments and decrease microglial activation in Tg2576 mice, while WIN55,212-2 was ineffective. Moreover, both cannabinoids significantly reduced the increase of COX-2, TNF- $\alpha$, and cortical A $\beta$ levels, suggesting a critical role of CB2 in inflammatory processes in AD (Martin-Moreno et al., 2012) (Figure 1).

From this scenario has emerged that the pleiotropic effects of CB2 agonists and the growing number of preclinical effects on $\mathrm{AD}$ rodent models should engage the interest of the research community and be seen as a valuable potential alternative treatment strategy to slow the progression and reduce the symptoms of cognitive decline in $\mathrm{AD}$.

\section{CB2 RECEPTORS AND PARKINSON'S DISEASE}

$\mathrm{PD}$, the second most common neurodegenerative disease, is characterized by the progressive loss of dopaminergic neurons primarily in the substantia nigra (SN) affecting the circuits of the basal ganglia resulting in bradykinesia, rigidity and tremors (de Lau and Breteler, 2006; Branchi et al., 2008, 2010; Bartels and Leenders, 2009). Current treatments include dopaminergic replacement therapies, which do alleviate some of the symptoms but there are no available therapies that reverse any of the underlying pathological mechanisms (Calne et al., 2005; Trapani et al., 2011; Denora et al., 2012; Di Gioia et al., 2015).

Moreover, there is an urgent need for a novel intervention aimed at the prevention of dyskinesia induced by long-term treatment with levodopa. To this regard, a randomized doubleblind crossover study showed that cannabis, which contains

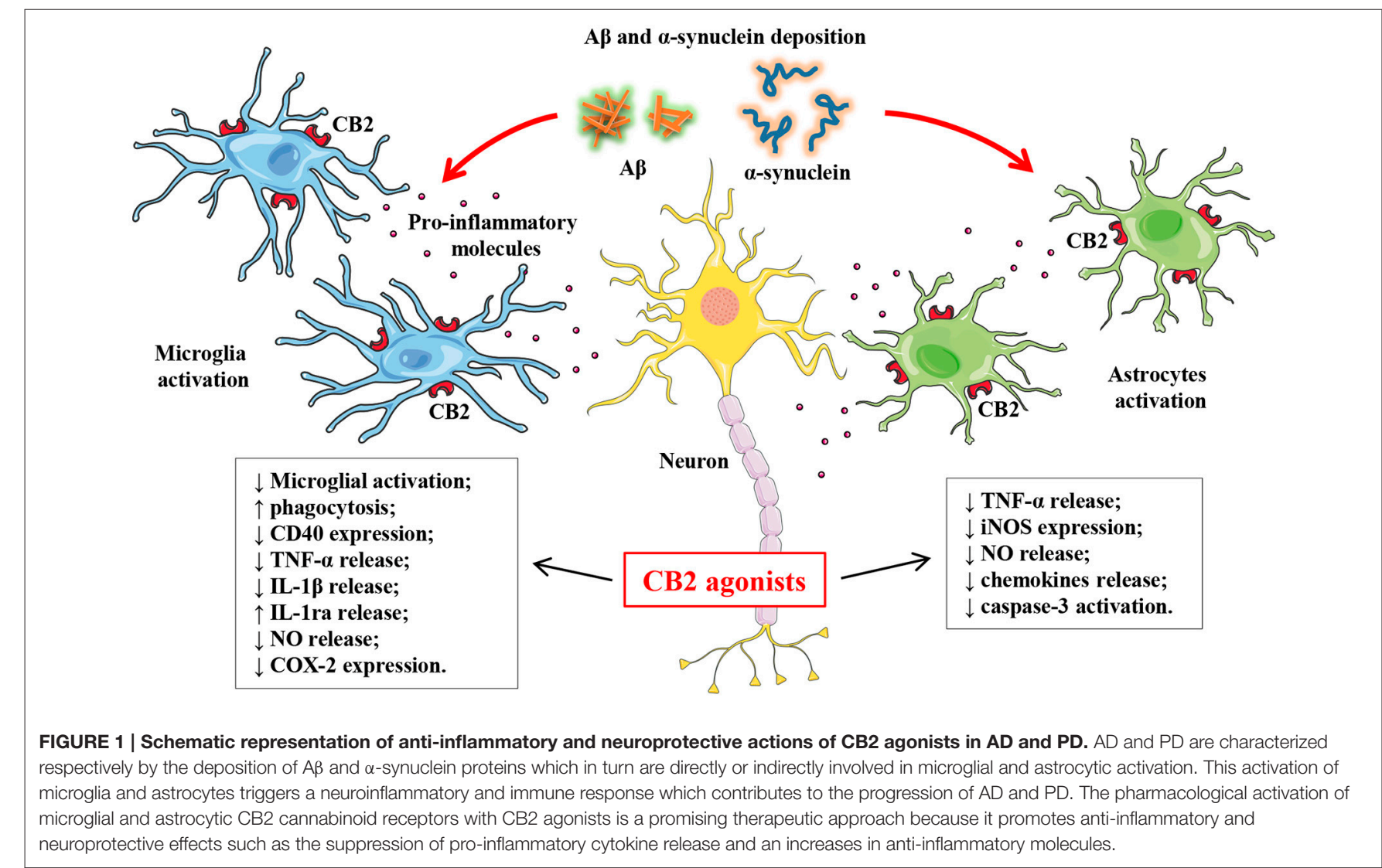


more than 70 different cannabinoids (Mechoulam, 2005), failed to demonstrate efficacy in treating dyskinetic patients with PD (Carroll et al., 2004). Unfortunately, the latter study suffered from methodological issues such as including small numbers of patients, and having inadequate power to detect a small change in dyskinesia.

$\mathrm{PD}$ is accompanied by multiple changes in the brain that underlie the progression of the disease. In this context, inflammation is an important pathogenic factor in sporadic PD, where it is thought to disable or kill dopaminergic neurons of the $\mathrm{SN}$, which contributes to the dopaminergic denervation of the striatum.

The involvement of inflammation in PD has been initially investigated by McGeer et al. (1988), who showed microglia activation in the $\mathrm{SN}$ of patients at post-mortem. Afterwards, more evidence has accumulated that highlights the role of the neuroinflammation in the pathogenesis of PD. In line with this, in vivo studies using structural brain imaging have demonstrated in the nigrostriatal system of PD patients the presence of activated microglia and an increase of proinflammatory cytokines, including TNF- $\alpha$, IL-1 $\beta$, IL-2, IL-4, and IL-6 (Ouchi et al., 2005; Gerhard et al., 2006; Taylor et al., 2013).

$\alpha$-synuclein ( $\alpha$-syn), the major component of Lewy bodies, is another pre-disposing element in PD etiology (Spillantini et al., 1998; Aureli et al., 2014). Missense mutations in the $\alpha$-syn gene have been identified to cause autosomal dominant familial PD (Polymeropoulos et al., 1997; Krüger et al., 1998; Zarranz et al., 2004). Several lines of evidence suggest that $\alpha$-syn may play an important role in the microglia-mediated inflammatory response in PD (Zhang et al., 2005; Austin et al., 2006; Reynolds et al., 2007, 2008; Thomas et al., 2007; Gao et al., 2008; Klegeris et al., 2008; Aureli et al., 2014). It is believed that genetic and environmental factors may initiate the neurodegeneration, which is further sustained or exacerbated by neuroinflammation leading to a "self-sustaining" process (Tansey and Goldberg, 2010). Therefore, effective anti-inflammatory intervention may arrest this cyclical process and counteract the neuroinflammationinduced neuronal degeneration.

Recently, in post-mortem study it has been demonstrated that PD patients showed elevated expression of CB2 receptors in microglial cells of SN (Gómez-Gálvez et al., 2016). In this context, as for $\mathrm{AD}$, converging evidence indicates that CB2 receptor may represent a promising anti-inflammatory target in PD (Figure 1, Table 1). This hypothesis comes from numerous studies where the pharmacological activation of microglial CB2 receptors produced a reduction of microglial activation and functional deficits in the 1-methyl-4-phenyl1,2,3,6-tetrahydropyridine (MPTP) mouse model of PD (Price et al., 2009), the suppression of pro-inflammatory cytokine release (Molina-Holgado et al., 2002; Klegeris et al., 2003; Ehrhart et al., 2005), and an increase in anti-inflammatory cytokines (Molina-Holgado et al., 2003). Moreover, CB2 receptor-deficient mice have shown an exacerbation of the PD pathology with increased microglial activation, neural alterations and functional deficits. Similar effects were also observed in other models of PD, such as MPTP-lesioned and lipopolysaccharide- (LPS)-injected mice (Price et al., 2009; García et al., 2011; Gómez-Gálvez et al., 2016). Moreover, the genetic ablation of the CB2 receptor protects against nigro-striatal damage following 6hydroxydopamine (6-OHDA) lesion in mice (Ternianov et al., 2012).

Neuroprotection has been provided by synthetic cannabinoids such as the CP55,940, CB1/CB2 full agonist (Jimenez-DelRio et al., 2008), which acts through CB receptor-independent mechanisms, and involves the control of endogenous antioxidant defenses. In particular, authors found that CP55,940 protects Drosophila melanogaster mutants which lack CB receptors (McPartland et al., 2001; Elphick and Egertová, 2005), and alleviates the toxicity induced by paraquat (Jimenez-Del-Rio et al., 2008). The latter effect was exerted by the inactivation of JNK signaling and CB receptors were not involved (Jimenez-DelRio et al., 2008). Other findings concerning the possible off-target effects of $\mathrm{CB}$ agonists were obtained also from in vivo studies, in which mice genetically deleted of $\mathrm{CB}$ receptors were treated with molecules targeting "non-cannabinoids" receptors (see for review Pertwee et al., 2010).

Selective CB2 receptor agonists induced gains of function in MPTP-lesioned mice (Price et al., 2009) and LPS-injected mice (García et al., 2011), but not in 6-OHDA-lesioned rats (García-Arencibia et al., 2007). The lack of effects of CB2 agonists may be due to a lower inflammatory response induced by 6 OHDA compared to that caused by LPS and MPTP (Price et al., 2009; García et al., 2011). In particular, HU-308, the selective CB2 agonist, reversed the LPS-induced reduction of tyrosine hydroxylase positive $\left(\mathrm{TH}^{+}\right)$neurons and the elevation of CD68 immunostaining in the striatum, which identifies activated microglia and infiltrated peripheral macrophages. Moreover, authors found that HU-308 significantly reduced increases in striatal iNOS gene expression following an LPS insult (Gómez-Gálvez et al., 2016). In line with these results, García and colleagues found that HU-308 preserved $\mathrm{TH}^{+}$neurons in the SN of LPS-injected mice (García et al., 2011).

A comprehensive study conducted by Price et al. (2009) demonstrated that the chronic treatment with the nonselective CB receptor agonist WIN55,212-2 protected against MPTP-induced loss of $\mathrm{TH}^{+}$neurons in the SN pars compacta $(\mathrm{SNc})$, independently of $\mathrm{CB} 1$ receptor activation. In fact, the authors found that WIN55,212-2 was still able to protect $\mathrm{TH}^{+}$neurons from MPTP-lesioned CB1 receptordeficient mice. Moreover, WIN55,212-2 increased the levels of dopamine and 3,4-dihydroxyphenylacetic acid in the SNc and dorsal striatum of MPTP-lesioned mice and reversed MPTP-associated motor deficits. WIN55,212-2 or JWH015, agonist of CB2 receptor, reduced MPTP-induced microglial infiltration. The suppressive effect of WIN55,212-2 and JWH015 on microglia was due specifically to CB2 activation as it was reversed by the CB2 antagonist JTE (Price et al., 2009).

Unlike targeting CB2 receptor signaling, the activation of $\mathrm{CB} 1$ receptors may cause hypokinetic side effects that could aggravate the major symptoms of $\mathrm{PD}$, such as bradykinesia (García-Arencibia et al., 2009). Therefore, the modulation of $\mathrm{CB} 1$ receptors seems not to be a promising target for therapeutic intervention in PD. However, $\mathrm{CB} 1$ activation may 
alleviate the levodopa-induced dyskinesia, a motor complication resulting from long-term use of levodopa (Morgese et al., 2007, 2009).

Taken together these results demonstrate that $\mathrm{CB} 2$ receptors play an important role in the pathophysiology of PD and that their activation with selective agonist may lead to neuroprotective effect in the neurodegenerative processes of PD.

\section{CONCLUSIONS}

Several lines of evidence suggest a major involvement of inflammation in the neurodegenerative process and therapeutic intervention strategies limiting the inflammatory responses secondary to microglial activation have been proposed by different authors based on many preclinical researches. Furthermore, recent approaches to the development of novel therapeutic strategies for neurodegenerative diseases have focused on their neuroprotective properties rather than concentrating on palliating symptoms of the diseases. Because cannabinoids possess both anti-inflammatory and neuroprotective actions, the use of $\mathrm{CB} 2$ receptor agonists offers an interesting, novel and promising therapeutic approach for a range of neurodegenerative disorders.

\section{REFERENCES}

Arroyo, D. S., Soria, J. A., Gaviglio, E. A., Rodriguez-Galan, M. C., and Iribarren, P. (2011). Toll-like receptors are key players in neurodegeneration. Int. Immunopharmacol. 11, 1415-1421. doi: 10.1016/j.intimp.2011.05.006

Aureli, C., Cassano, T., Masci, A., Francioso, A., Martire, S., Cocciolo, A., et al. (2014). 5-S-cysteinyldopamine neurotoxicity: influence on the expression of $\alpha$ synuclein and ERp57 in cellular and animal models of Parkinson's disease. J. Neurosci. Res. 92, 347-358. doi: 10.1002/jnr.23318

Austin, S. A., Floden, A. M., Murphy, E. J., and Combs, C. K. (2006). Alphasynuclein expression modulates microglial activation phenotype. J. Neurosci. 26, 10558-10563. doi: 10.1523/JNEUROSCI.1799-06.2006

Bartels, A. L., and Leenders, K. L. (2009). Parkinson's disease: the syndrome, the pathogenesis and pathophysiology. Cortex 45, 915-921. doi: 10.1016/j.cortex.2008.11.010

Bedse, G., Romano, A., Cianci, S., Lavecchia, A. M., Lorenzo, P., Elphick, M. R., et al. (2014). Altered expression of the CB1 cannabinoid receptor in the triple transgenic mouse model of Alzheimer's disease. J. Alzheimers. Dis. 40, 701-712. doi: 10.3233/JAD-131910

Bedse, G., Romano, A., Lavecchia, A. M., Cassano, T., and Gaetani, S. (2015). The role of endocannabinoid signaling in the molecular mechanisms of neurodegeneration in Alzheimer's disease. J. Alzheimers. Dis. 43, 1115-1136. doi: 10.3233/JAD-141635

Benito, C., Núñez, E., Tolón, R. M., Carrier, E. J., Rábano, A., Hillard, C. J., et al. (2003). Cannabinoid CB2 receptors and fatty acid amide hydrolase are selectively overexpressed in neuritic plaque-associated glia in Alzheimer's disease brains. J. Neurosci. 23, 11136-11141.

Benito, C., Tolón, R. M., Pazos, M. R., Núñez, E., Castillo, A. I., and Romero, J. (2008). Cannabinoid CB2 receptors in human brain inflammation. Br. J. Pharmacol. 153, 277-285. doi: 10.1038/sj.bjp.0707505

Benveniste, E. N., Nguyen, V. T., and Wesemann, D. R. (2004). Molecular regulation of CD40 gene expression in macrophages and microglia. Brain Behav. Immun. 18, 7-12. doi: 10.1016/j.bbi.2003.09.001

Bonnet, A. E., and Marchalant, Y. (2015). Potential therapeutical contributions of the endocannabinoid system towards aging and Alzheimer's disease. Aging Dis. 6, 400-405. doi: 10.14336/AD.2015.0617
Moreover, modulation of $\mathrm{CB} 2$ receptor function has considerable therapeutic advantages over the modulation of the CB1 receptor, since the selective expression of CB2 receptors on the microglial cells provides a highly specialized target, without the psychoactivity due to CB1 activation. Although more studies are necessary to dissect the molecular mechanisms which lead to changes in CB2 receptor expression in $\mathrm{AD}$ and $\mathrm{PD}$, these studies suggest that CB2 receptors may be key regulators of neuroinflammation and may be successfully targeted by therapeutic intervention.

\section{AUTHOR CONTRIBUTIONS}

All authors have contributed to the writing, design and preparation of figures. Coordination of efforts has been carried out by the senior authors (TC and SG) of the three participating laboratories.

\section{FUNDING}

This study was supported by Grant PRIN 2012 (to SG) (PRIN: 2012JTX3KL_002) and the Post-Doctoral fellowship of Dr Adele Romano (FIR: RBFR12DELS_003).

Branchi, I., D’Andrea, I., Armida, M., Carnevale, D., Ajmone-Cat, M. A., Pèzzola, A., et al. (2010). Striatal 6-OHDA lesion in mice: investigating early neurochemical changes underlying Parkinson's disease. Behav. Brain Res. 208, 137-143. doi: 10.1016/j.bbr.2009.11.020

Branchi, I., D’Andrea, I., Armida, M., Cassano, T., Pèzzola, A., Potenza, R. L., et al. (2008). Nonmotor symptoms in Parkinson's disease: investigating early-phase onset of behavioral dysfunction in the 6-hydroxydopamine-lesioned rat model. J. Neurosci. Res. 86, 2050-2061. doi: 10.1002/jnr.21642

Brown, S. M., Wager-Miller, J., and Mackie, K. (2002). Cloning and molecular characterization of the rat CB2 cannabinoid receptor. Biochim. Biophys. Acta 1576, 255-264. doi: 10.1016/S0167-4781(02)00341-X

Buckley, N. E., McCoy, K. L., Mezey, E., Bonner, T., Zimmer, A., Felder, C. C., et al. (2000). Immunomodulation by cannabinoids is absent in mice deficient for the cannabinoid CB(2) receptor. Eur. J. Pharmacol. 396, 141-149. doi: 10.1016/S0014-2999(00)00211-9

Cabral, G. A., and Griffin-Thomas, L. (2009). Emerging role of the cannabinoid receptor $\mathrm{CB} 2$ in immune regulation: therapeutic prospects for neuroinflammation. Expert. Rev. Mol. Med. 11:e3. doi: 10.1017/S1462399409000957

Callén, L., Moreno, E., Barroso-Chinea, P., Moreno-Delgado, D., Cortés, A., Mallol, J., et al. (2012). Cannabinoid receptors CB1 and CB2 form functional heteromers in brain. J. Biol. Chem. 287, 20851-20865. doi: 10.1074/jbc.M111.335273

Calne, D., Schulzer, M., Mak, E., and Stoessl, A. J. (2005). Treatment for the progression of Parkinson's disease. Lancet Neurol. 4, 206. doi: 10.1016/S1474-4422(05)70026-0

Carroll, C. B., Bain, P. G., Teare, L., Liu, X., Joint, C., Wroath, C., et al. (2004). Cannabis for dyskinesia in Parkinson disease: a randomized double-blind crossover study. Neurology 63, 1245-1250. doi: 10.1212/01.WNL.0000140288.48796.8E

Cassano, T., Pace, L., Bedse, G., Lavecchia, A. M., De Marco, F., Gaetani, S., et al. (2016). Glutamate and mitochondria: two prominent players in the oxidative stress-induced neurodegeneration. Curr. Alzheimer Res. 13, 185-197. doi: 10.2174/1567205013666151218132725

Cassano, T., Serviddio, G., Gaetani, S., Romano, A., Dipasquale, P., Cianci, S., et al. (2012). Glutamatergic alterations and mitochondrial impairment 
in a murine model of Alzheimer disease. Neurobiol. Aging 33, 1121.e1-12. doi: 10.1016/j.neurobiolaging.2011.09.021

Chen, B., Bromley-Brits, K., He, G., Cai, F., Zhang, X., and Song, W. (2010). Effect of synthetic cannabinoid HU210 on memory deficits and neuropathology in Alzheimer's disease mouse model. Curr. Alzheimer Res. 7, 255-261. doi: $10.2174 / 156720510791050948$

Churcher, I. (2006). Tau therapeutic strategies for the treatment of Alzheimer's disease. Curr. Top. Med. Chem. 6, 579-595. doi: 10.2174/156802606776743057

Cravatt, B. F., Giang, D. K., Mayfield, S. P., Boger, D. L., Lerner, R. A., and Gilula, N. B. (1996). Molecular characterization of an enzyme that degrades neuromodulatory fatty-acid amides. Nature 384, 83-87. doi: 10.1038/384083a0

D’Addario, C., Micioni Di Bonaventura, M. V., Pucci, M., Romano, A., Gaetani, S., Ciccocioppo, R., et al. (2014). Endocannabinoid signaling and food addiction. Neurosci. Biobehav. Rev. 47:203-224. doi: 10.1016/j.neubiorev.2014.08.008

de Lau, L. M., and Breteler, M. M. (2006). Epidemiology of Parkinson's disease. Lancet Neurol. 5, 525-535. doi: 10.1016/S1474-4422(06)70471-9

Denora, N., Cassano, T., Laquintana, V., Lopalco, A., Trapani, A., Cimmino, C. S., et al. (2012). Novel codrugs with GABAergic activity for dopamine delivery in the brain. Int. J. Pharm. 437, 221-231. doi: 10.1016/j.ijpharm.2012.08.023

Devane, W. A., Hanus, L., Breuer, A., Pertwee, R. G., Stevenson, L. A., Griffin, G., et al. (1992). Isolation and structure of a brain constituent that binds to the cannabinoid receptor. Science 258, 1946-1949. doi: 10.1126/science.1470919

Di Gioia, S., Trapani, A., Mandracchia, D., De Giglio, E., Cometa, S., Mangini, V., et al. (2015). Intranasal delivery of dopamine to the striatum using glycol chitosan/sulfobutylether- $\beta$-cyclodextrin based nanoparticles. Eur. J. Pharm. Biopharm. 94, 180-193. doi: 10.1016/j.ejpb.2015.05.019

Di Iorio, G., Lupi, M., Sarchione, F., Matarazzo, I., Santacroce, R., Petruccelli, F., et al. (2013). The endocannabinoid system: a putative role in neurodegenerative diseases. Int. J. High Risk Behav. Addict. 2, 100-106. doi: 10.5812/ijhrba.9222

Di Marzo, V., Stella, N., and Zimmer, A. (2015). Endocannabinoid signalling and the deteriorating brain. Nat. Rev. Neurosci. 16, 30-42. doi: 10.1038/nrn3876

Dinh, T. P., Freund, T. F., and Piomelli, D. (2002). A role for monoglyceride lipase in 2-arachidonoylglycerol inactivation. Chem. Phys. Lipids. 121, 149-158. doi: 10.1016/S0009-3084(02)00150-0

Duan, Y., Dong, S., Gu, F., Hu, Y., and Zhao, Z. (2012). Advances in the pathogenesis of Alzheimer's disease: focusing on tau-mediated neurodegeneration. Transl. Neurodegener. 1:24. doi: 10.1186/2047-9158-1-24

Egertová, M., Cravatt, B. F., and Elphick, M. R. (2003). Comparative analysis of fatty acid amide hydrolase and $\mathrm{cb}(1)$ cannabinoid receptor expression in the mouse brain: evidence of a widespread role for fatty acid amide hydrolase in regulation of endocannabinoid signaling. Neuroscience 119, 481-496. doi: 10.1016/S0306-4522(03)00145-3

Ehrhart, J., Obregon, D., Mori, T., Hou, H., Sun, N., Bai, Y., et al. (2005). Stimulation of cannabinoid receptor 2 (CB2) suppresses microglial activation. J. Neuroinflammation. 2:29. doi: 10.1186/1742-2094-2-29

Elphick, M. R., and Egertová, M. (2005). The phylogenetic distribution and evolutionary origins of endocannabinoid signalling. Handb. Exp. Pharmacol. 168, 283-297. doi: 10.1007/3-540-26573-2_9

Esposito, G., Iuvone, T., Savani, C., Scuderi, C., De Filippis, D., Papa, M., et al. (2007). Opposing control of cannabinoid receptor stimulation on amyloidbeta-induced reactive gliosis: in vitro and in vivo evidence. J. Pharmacol. Exp. Ther. 322, 1144-1152. doi: 10.1124/jpet.107.121566

Fagan, S. G., and Campbell, V. A. (2014). The influence of cannabinoids on generic traits of neurodegeneration. Br. J. Pharmacol. 171, 1347-1360. doi: 10.1111/bph.12492

Fakhfouri, G., Ahmadiani, A., Rahimian, R., Grolla, A. A., Moradi, F., and Haeri, A. (2012). WIN55212-2 attenuates amyloid-beta-induced neuroinflammation in rats through activation of cannabinoid receptors and PPAR- $\gamma$ pathway. Neuropharmacology 63, 653-666. doi: 10.1016/j.neuropharm.2012.05.013

Fernández-Ruiz, J., García, C., Sagredo, O., Gómez-Ruiz, M., and de Lago, E. (2010). The endocannabinoid system as a target for the treatment of neuronal damage. Expert Opin. Ther. Targets 14, 387-404. doi: $10.1517 / 14728221003709792$

Fernández-Ruiz, J., Moro, M. A., and Martínez-Orgado, J. (2015). Cannabinoids in neurodegenerative disorders and stroke/brain trauma: from preclinical models to clinical applications. Neurotherapeutics 12, 793-806. doi: 10.1007/s13311-015-0381-7
Freund, T. F., Katona, I., and Piomelli, D. (2003). Role of endogenous cannabinoids in synaptic signaling. Physiol. Rev. 83, 1017-1066. doi: 10.1152/physrev.00004.2003

Gao, H. M., Kotzbauer, P. T., Uryu, K., Leight, S., Trojanowski, J. Q., and Lee, V. M. (2008). Neuroinflammation and oxidation/nitration of alpha-synuclein linked to dopaminergic neurodegeneration. J. Neurosci. 28, 7687-7698. doi: 10.1523/JNEUROSCI.0143-07.2008

García, C., Palomo-Garo, C., García-Arencibia, M., Ramos, J., Pertwee, R., and Fernández-Ruiz, J. (2011). Symptom-relieving and neuroprotective effects of the phytocannabinoid $\Delta^{9}$-THCV in animal models of Parkinson's disease. $B r$. J. Pharmacol. 163, 1495-1506. doi: 10.1111/j.1476-5381.2011.01278.x

García-Arencibia, M., García, C., Kurz, A., Rodríguez-Navarro, J. A., GispertSáchez, S., Mena, M. A., et al. (2009). Cannabinoid CB1 receptors are early downregulated followed by a further upregulation in the basal ganglia of mice with deletion of specific park genes. J. Neural. Transm. Suppl. 73, 269-275. doi: 10.1007/978-3-211-92660-4_22

García-Arencibia, M., González, S., de Lago, E., Ramos, J. A., Mechoulam, R., and Fernández-Ruiz, J. (2007). Evaluation of the neuroprotective effect of cannabinoids in a rat model of Parkinson's disease: importance of antioxidant and cannabinoids receptor-independent properties. Brain Res. 1134, 162-170. doi: 10.1016/j.brainres.2006.11.063

Gerhard, A., Pavese, N., Hotton, G., Turkheimer, F., Es, M., Hammers, A., et al. (2006). In vivo imaging of microglial activation with [11C](R)PK11195 PET in idiopathic Parkinson's disease. Neurobiol. Dis. 21, 404-412. doi: 10.1016/j.nbd.2005.08.002

Gómez-Gálvez, Y., Palomo-Garo, C., Fernández-Ruiz, J., and García, C. (2016). Potential of the cannabinoid $\mathrm{CB}(2)$ receptor as a pharmacological target against inflammation in Parkinson's disease. Prog. Neuropsychopharmacol. Biol. Psychiatry 64, 200-208. doi: 10.1016/j.pnpbp.2015.03.017

Griffin, G., Tao, Q., and Abood, M. E. (2000). Cloning and pharmacological characterization of the rat $\mathrm{CB}(2)$ cannabinoid receptor. J. Pharmacol. Exp. Ther. 292, 886-894.

Grünblatt, E., Bartl, J., Zehetmayer, S., Ringel, T. M., Bauer, P., Riederer, P., et al. (2009). Gene expression as peripheral biomarkers for sporadic Alzheimer's disease. J. Alzheimers. Dis. 16, 627-634. doi: 10.3233/JAD-2009-0996

Halleskog, C., Mulder, J., Dahlström, J., Mackie, K., Hortobágyi, T., Tanila, H., et al. (2011). WNT signaling in activated microglia is proinflammatory. Glia 59, 119-131. doi: 10.1002/glia.21081

Halliday, G. M., and Stevens, C. H. (2011). Glia: initiators and progressors of pathology in Parkinson's disease. Mov. Disord. 26, 6-17. doi: $10.1002 / \mathrm{mds} .23455$

Horti, A. G., Gao, Y., Ravert, H. T., Finley, P., Valentine, H., Wong, D. F., et al. (2010). Synthesis and biodistribution of [11C]A-836339, a new potential radioligand for PET imaging of cannabinoid type 2 receptors (CB2). Bioorg. Med. Chem. 18, 5202-5207. doi: 10.1016/j.bmc.2010.05.058

Howlett, A. C., Barth, F., Bonner, T. I., Cabral, G., Casellas, P., Devane, W. A., et al. (2002). International union of pharmacology. XXVII. Classification of cannabinoid receptors. Pharmacol. Rev. 54, 161-202. doi: 10.1124/pr.54.2.161

Jimenez-Del-Rio, M., Daza-Restrepo, A., and Velez-Pardo, C. (2008). The cannabinoid CP55,940 prolongs survival and improves locomotor activity in Drosophila melanogaster against paraquat: implications in Parkinson's disease. Neurosci. Res. 61, 404-411. doi: 10.1016/j.neures.2008.04.011

Kalifa, S., Polston, E. K., Allard, J. S., and Manaye, K. F. (2011). Distribution patterns of cannabinoid CB1 receptors in the hippocampus of APPswe/PS1 $\triangle \mathrm{E} 9$ double transgenic mice. Brain Res. 1376, 94-100. doi: 10.1016/j.brainres.2010.12.061

Klegeris, A., Bissonnette, C. J., and McGeer, P. L. (2003). Reduction of human monocytic cell neurotoxicity and cytokine secretion by ligands of the cannabinoid-type CB2 receptor. Br. J. Pharmacol. 139, 775-786. doi: 10.1038/sj.bjp.0705304

Klegeris, A., Pelech, S., Giasson, B. I., Maguire, J., Zhang, H., McGeer, E. G., et al. (2008). Alpha-synuclein activates stress signaling protein kinases in THP-1 cells and microglia. Neurobiol. Aging 29, 739-752. doi: 10.1016/j.neurobiolaging.2006.11.013

Klein, T. W., Newton, C., Larsen, K., Lu, L., Perkins, I., Nong, L., et al. (2003). The cannabinoid system and immune modulation. J. Leukoc. Biol. 74, 486-496. doi: $10.1189 / \mathrm{jlb} .0303101$ 
Krüger, R., Kuhn, W., Müller, T., Woitalla, D., Graeber, M., Kösel, S., et al. (1998). Ala30Pro mutation in the gene encoding alpha-synuclein in Parkinson's disease. Nat. Genet. 18, 106-108. doi: 10.1038/ng0298-106

Lastres-Becker, I., Cebeira, M., de Ceballos, M. L., Zeng, B. Y., Jenner, P., Ramos, J. A., et al. (2001). Increased cannabinoid CB1 receptor binding and activation of GTP-binding proteins in the basal ganglia of patients with Parkinson's syndrome and of MPTP-treated marmosets. Eur. J. Neurosci. 14, 1827-1832. doi: 10.1046/j.0953-816x.2001.01812.x

Liu, Q. R., Pan, C. H., Hishimoto, A., Li, C. Y., Xi, Z. X., Llorente-Berzal, A., et al. (2009). Species differences in cannabinoid receptor 2 (CNR2 gene): identification of novel human and rodent CB2 isoforms, differential tissue expression and regulation by cannabinoid receptor ligands. Genes Brain Behav. 8, 519-530. doi: 10.1111/j.1601-183X.2009.00498.x

Lu, H. C., and Mackie, K. (2015). An introduction to the endogenous cannabinoid system. Biol. Psychiatry 79, 516-525. doi: 10.1016/j.biopsych.2015.07.028

Maccarrone, M., Bari, M., Battista, N., Di Rienzo, M., and Finazzi-Agrò, A. (2001). Endogenous cannabinoids in neuronal and immune cells: toxic effects, levels and degradation. Funct. Neurol. 16(4 Suppl.), 53-60.

Maccarrone, M., Dainese, E., and Oddi, S. (2010). Intracellular trafficking of anandamide: new concepts for signaling. Trends Biochem. Sci. 35, 601-608. doi: 10.1016/j.tibs.2010.05.008

Mackie, K. (2005). Distribution of cannabinoid receptors in the central and peripheral nervous system. Handb. Exp. Pharmacol. 168, 299-325. doi: 10.1007/3-540-26573-2_10

Manuel, I., González de San Román, E., Giralt, M. T., Ferrer, I., and RodríguezPuertas, R. (2014). Type-1 cannabinoid receptor activity during Alzheimer's disease progression. J. Alzheimers. Dis. 42, 761-766. doi: 10.3233/JAD140492

Marsicano, G., Moosmann, B., Hermann, H., Lutz, B., and Behl, C. (2002). Neuroprotective properties of cannabinoids against oxidative stress: role of the cannabinoid receptor CB1. J. Neurochem. 80, 448-456. doi: 10.1046/j.0022-3042.2001.00716.x

Martin-Moreno, A. M., Brera, B., Spuch, C., Carro, E., García-García, L., Delgado, M., et al. (2012). Prolonged oral cannabinoid administration prevents neuroinflammation, lowers $\beta$-amyloid levels and improves cognitive performance in Tg APP 2576 mice. J. Neuroinflammation. 9:8. doi: 10.1186/1742-2094-9-8

McGeer, P. L., Itagaki, S., Boyes, B. E., and McGeer, E. G. (1988). Reactive microglia are positive for HLA-DR in the substantia nigra of Parkinson's and Alzheimer's disease brains. Neurology 38, 1285-1291. doi: 10.1212/WNL.38.8.1285

McGeer, P. L., McGeer, E. G., and Yasojima, K. (2000). Alzheimer disease and neuroinflammation. J. Neural Transm. Suppl. 59, 53-57. doi: 10.1007/978-3-7091-6781-6_8

McPartland, J., Di Marzo, V., De Petrocellis, L., Mercer, A., and Glass, M. (2001). Cannabinoid receptors are absent in insects. J. Comp. Neurol. 436, 423-429. doi: $10.1002 / \mathrm{cne} .1078$

Mecha, M., Carrillo-Salinas, F. J., Feliú, A., Mestre, L., and Guaza, C. (2016). Microglia activation states and cannabinoid system: therapeutic implications. Pharmacol. Ther. 166:40-55. doi: 10.1016/j.pharmthera.2016.06.011

Mechoulam, R. (1970). Marihuana chemistry. Science 168, 1159-1166. doi: $10.1126 /$ science.168.3936.1159

Mechoulam, R. (2005). Plant cannabinoids: a neglected pharmacological treasure trove. Br. J. Pharmacol. 146, 913-915. doi: 10.1038/sj.bjp.0706415

Mechoulam, R., Ben-Shabat, S., Hanus, L., Ligumsky, M., Kaminski, N. E., Schatz, A. R., et al. (1995). Identification of an endogenous 2-monoglyceride, present in canine gut, that binds to cannabinoid receptors. Biochem. Pharmacol. 50, 83-90. doi: 10.1016/0006-2952(95)00109-D

Mechoulam, R., and Gaoni, Y. (1965). A total synthesis of DL-delta-1tetrahydrocannabinol, the active constituent of hashish. J. Am. Chem. Soc. 87, 3273-3275. doi: 10.1021/ja01092a065

Mechoulam, R., and Parker, L. A. (2013). The endocannabinoid system and the brain. Annu. Rev. Psychol. 64, 21-47. doi: 10.1146/annurev-psych-113011143739

Micale, V., Di Marzo, V., Sulcova, A., Wotjak, C. T., and Drago, F. (2013). Endocannabinoid system and mood disorders: priming a target for new therapies. Pharmacol. Ther. 138, 18-37. doi: 10.1016/j.pharmthera.2012.12.002

Molina-Holgado, F., Molina-Holgado, E., Guaza, C., and Rothwell, N. J. (2002). Role of $\mathrm{CB} 1$ and $\mathrm{CB} 2$ receptors in the inhibitory effects of cannabinoids on lipopolysaccharide-induced nitric oxide release in astrocyte cultures. $J$. Neurosci. Res. 67, 829-836. doi: 10.1002/jnr.10165

Molina-Holgado, F., Pinteaux, E., Moore, J. D., Molina-Holgado, E., Guaza, C., Gibson, R. M., et al. (2003). Endogenous interleukin-1 receptor antagonist mediates anti-inflammatory and neuroprotective actions of cannabinoids in neurons and glia. J. Neurosci. 23, 6470-6474.

Morgese, M. G., Cassano, T., Cuomo, V., and Giuffrida, A. (2007). Anti-dyskinetic effects of cannabinoids in a rat model of Parkinson's disease: role of $\mathrm{CB}(1)$ and TRPV1 receptors. Exp. Neurol. 208, 110-119. doi: 10.1016/j.expneurol.2007.07.021

Morgese, M. G., Cassano, T., Gaetani, S., Macheda, T., Laconca, L., Dipasquale, P., et al. (2009). Neurochemical changes in the striatum of dyskinetic rats after administration of the cannabinoid agonist WIN55,212-2. Neurochem. Int. 54, 56-64. doi: 10.1016/j.neuint.2008.10.007

Mulder, J., Zilberter, M., Pasquaré, S. J., Alpár, A., Schulte, G., Ferreira, S. G., et al. (2011). Molecular reorganization of endocannabinoid signalling in Alzheimer's disease. Brain 134(Pt 4), 1041-1060. doi: 10.1093/brain/awr046

Munoz, L., and Ammit, A. J. (2010). Targeting p38 MAPK pathway for the treatment of Alzheimer's disease. Neuropharmacology 58, 561-568. doi: 10.1016/j.neuropharm.2009.11.010

Nong, L., Newton, C., Friedman, H., and Klein, T. W. (2001). CB1 and CB2 receptor mRNA expression in human peripheral blood mononuclear cells (PBMC) from various donor types. Adv. Exp. Med. Biol. 493, 229-233. doi: 10.1007/0-306-47611-8_27

Núñez, E., Benito, C., Pazos, M. R., Barbachano, A., Fajardo, O., González, S., et al. (2004). Cannabinoid CB2 receptors are expressed by perivascular microglial cells in the human brain: an immunohistochemical study. Synapse 53, 208-213. doi: 10.1002/syn.20050

Núñez, E., Benito, C., Tolón, R. M., Hillard, C. J., Griffin, W. S., and Romero, J. (2008). Glial expression of cannabinoid $\mathrm{CB}(2)$ receptors and fatty acid amide hydrolase are beta amyloid-linked events in Down's syndrome. Neuroscience 151, 104-110. doi: 10.1016/j.neuroscience.2007.10.029

Ouchi, Y., Yoshikawa, E., Sekine, Y., Futatsubashi, M., Kanno, T., Ogusu, T., et al. (2005). Microglial activation and dopamine terminal loss in early Parkinson's disease. Ann. Neurol. 57, 168-175. doi: 10.1002/ana.20338

Pertwee, R. G., Howlett, A. C., Abood, M. E., Alexander, S. P., Di Marzo, V., Elphick, M. R., et al. (2010). International union of basic and clinical pharmacology. LXXIX. Cannabinoid receptors and their ligands: beyond CB1 and CB2. Pharmacol Rev. 62, 588-631. doi: 10.1124/pr.110.003004

Polymeropoulos, M. H., Lavedan, C., Leroy, E., Ide, S. E., Dehejia, A., Dutra, A., et al. (1997). Mutation in the alpha-synuclein gene identified in families with Parkinson's disease. Science 276, 2045-2047. doi: 10.1126/science.276.5321.2045

Price, D. A., Martinez, A. A., Seillier, A., Koek, W., Acosta, Y., Fernandez, E., et al. (2009). WIN55,212-2, a cannabinoid receptor agonist, protects against nigrostriatal cell loss in the 1-methyl-4-phenyl-1,2,3,6-tetrahydropyridine mouse model of Parkinson's disease. Eur. J. Neurosci. 29, 2177-2186. doi: 10.1111/j.1460-9568.2009.06764.x

Ramírez, B. G., Blázquez, C., Gómez del Pulgar, T., Guzmán, M., and de Ceballos, M. L. (2005). Prevention of Alzheimer's disease pathology by cannabinoids: neuroprotection mediated by blockade of microglial activation. J. Neurosci. 25, 1904-1913. doi: 10.1523/JNEUROSCI.4540-04.2005

Reed-Geaghan, E. G., Savage, J. C., Hise, A. G., and Landreth, G. E. (2009). CD14 and toll-like receptors 2 and 4 are required for fibrillar A $\{$ beta\}-stimulated microglial activation. J. Neurosci. 29, 11982-11992. doi: 10.1523/JNEUROSCI.3158-09.2009

Reynolds, A. D., Glanzer, J. G., Kadiu, I., Ricardo-Dukelow, M., Chaudhuri, A., Ciborowski, P., et al. (2007). Nitrated alpha-synuclein-activated microglial profiling for Parkinson's disease. J. Neurochem. 104, 1504-1525. doi: 10.1111/j.1471-4159.2007.05087.x

Reynolds, A. D., Kadiu, I., Garg, S. K., Glanzer, J. G., Nordgren, T., Ciborowski, P., et al. (2008). Nitrated alpha-synuclein and microglial neuroregulatory activities. J. Neuroimmune Pharmacol. 3, 59-74. doi: 10.1007/s11481-0089100-z

Rodríguez-Cueto, C., Benito, C., Fernández-Ruiz, J., Romero, J., HernándezGálvez, M., and Gómez-Ruiz, M. (2014). Changes in $\mathrm{CB}(1)$ and $\mathrm{CB}(2)$ receptors in the post-mortem cerebellum of humans affected by spinocerebellar ataxias. Br. J. Pharmacol. 171, 1472-1489. doi: 10.1111/bph.12283 
Rohn, T. T. (2010). The role of caspases in Alzheimer's disease; potential novel therapeutic opportunities. Apoptosis 15, 1403-1409. doi: $10.1007 /$ s10495-010-0463-2

Saito, V. M., Wotjak, C. T., and Moreira, F. A. (2010). Pharmacological exploitation of the endocannabinoid system: new perspectives for the treatment of depression and anxiety disorders? Revista Brasileira de Psiquiatria 32, S7-S14.

Sánchez, A. J., and García-Merino, A. (2012). Neuroprotective agents: cannabinoids. Clin. Immunol. 142, 57-67. doi: 10.1016/j.clim.2011.02.010

Sastre, M., Klockgether, T., and Heneka, M. T. (2006). Contribution of inflammatory processes to Alzheimer's disease: molecular mechanisms. Int. J. Dev. Neurosci. 24, 167-176. doi: 10.1016/j.ijdevneu.2005.11.014

Serviddio, G., Romano, A. D., Cassano, T., Bellanti, F., Altomare, E., and Vendemiale, G. (2011). Principles and therapeutic relevance for targeting mitochondria in aging and neurodegenerative diseases. Curr. Pharm. Des. 17, 2036-2055. doi: 10.2174/138161211796904740

Sheng, W. S., Hu, S., Min, X., Cabral, G. A., Lokensgard, J. R., and Peterson, P. K. (2005). Synthetic cannabinoid WIN55,212-2 inhibits generation of inflammatory mediators by IL-1beta-stimulated human astrocytes. Glia 49, 211-219. doi: 10.1002/glia.20108

Shire, D., Calandra, B., Rinaldi-Carmona, M., Oustric, D., Pessègue, B., BonninCabanne, O., et al. (1996). Molecular cloning, expression and function of the murine CB2 peripheral cannabinoid receptor. Biochim. Biophys. Acta 1307, 132-136. doi: 10.1016/0167-4781(96)00047-4

Solas, M., Francis, P. T., Franco, R., and Ramirez, M. J. (2013). CB2 receptor and amyloid pathology in frontal cortex of Alzheimer's disease patients. Neurobiol. Aging 34, 805-808. doi: 10.1016/j.neurobiolaging.2012.06.005

Spillantini, M. G., Crowther, R. A., Jakes, R., Hasegawa, M., and Goedert, M. (1998). alpha-Synuclein in filamentous inclusions of Lewy bodies from Parkinson's disease and dementia with lewy bodies. Proc. Natl. Acad. Sci. U.S.A. 95, 6469-6473. doi: 10.1073/pnas.95.11.6469

Spoto, B., Fezza, F., Parlongo, G., Battista, N., Sgro', E., Gasperi, V., et al. (2006). Human adipose tissue binds and metabolizes the endocannabinoids anandamide and 2-arachidonoylglycerol. Biochimie 88, 1889-1897. doi: 10.1016/j.biochi.2006.07.019

Stella, N. (2010). Cannabinoid and cannabinoid-like receptors in microglia, astrocytes, and astrocytomas. Glia 58, 1017-1030. doi: 10.1002/glia.20983

Sugiura, T., Kondo, S., Kishimoto, S., Miyashita, T., Nakane, S., Kodaka, T., et al. (2000). Evidence that 2-arachidonoylglycerol but not $\mathrm{N}$ palmitoylethanolamine or anandamide is the physiological ligand for the cannabinoid CB2 receptor. Comparison of the agonistic activities of various cannabinoid receptor ligands in HL-60 cells. J. Biol. Chem. 275, 605-612. doi: $10.1074 / j b c .275 .1 .605$

Sugiura, T., Kondo, S., Sukagawa, A., Nakane, S., Shinoda, A., Itoh, K., et al. (1995). 2-Arachidonoylglycerol: a possible endogenous cannabinoid receptor ligand in brain. Biochem. Biophys. Res. Commun. 215, 89-97. doi: 10.1006/bbrc.1995.2437

Tansey, M. G., and Goldberg, M. S. (2010).Neuroinflammation in Parkinson's disease: its role in neuronal death and implications for therapeutic intervention. Neurobiol. Dis. 37, 510-518. doi: 10.1016/j.nbd.2009.11.004

Taylor, J. M., Main, B. S., and Crack, P. J. (2013). Neuroinflammation and oxidative stress: co-conspirators in the pathology of Parkinson's disease. Neurochem. Int. 62, 803-819. doi: 10.1016/j.neuint.2012.12.016

Ternianov, A., Pérez-Ortiz, J. M., Solesio, M. E., García-Gutiérrez, M. S., OrtegaÁlvaro, A., Navarrete, F., et al. (2012). Overexpression of CB2 cannabinoid receptors results in neuroprotection against behavioral and neurochemical alterations induced by intracaudate administration of 6-hydroxydopamine. Neurobiol. Aging 33, 421.e1-16. doi: 10.1016/j.neurobiolaging.2010.09.012

Thomas, M. P., Chartrand, K., Reynolds, A., Vitvitsky, V., Banerjee, R., and Gendelman, H. E. (2007). Ion channel blockade attenuates aggregated alpha synuclein induction of microglial reactive oxygen species: relevance for the pathogenesis of Parkinson's disease. J. Neurochem. 100, 503-519. doi: 10.1111/j.1471-4159.2006.04315.x

Trapani, A., De Giglio, E., Cafagna, D., Denora, N., Agrimi, G., Cassano, T., et al. (2011). Characterization and evaluation of chitosan nanoparticles for dopamine brain delivery. Int. J. Pharm. 419, 1296-1307. doi: 10.1016/j.ijpharm.2011.07.036

Turcotte, C., Blanchet, M. R., Laviolette, M., and Flamand, N. (2016). The CB(2) receptor and its role as a regulator of inflammation. Cell. Mol. Life Sci. 73, 4449-4470. doi: 10.1007/s00018-016-2300-4

Van Sickle, M. D., Duncan, M., Kingsley, P. J., Mouihate, A., Urbani, P., Mackie, $\mathrm{K}$., et al. (2005). Identification and functional characterization of brainstem cannabinoid CB2 receptors. Science 310, 329-332. doi: 10.1126/science.1115740

Vendel, E., and de Lange, E. C. (2014). Functions of the CB1 and CB2 receptors in neuroprotection at the level of the blood-brain barrier. Neuromol. Med. 16, 620-642. doi: 10.1007/s12017-014-8314-x

Viscomi, M. T., Oddi, S., Latini, L., Pasquariello, N., Florenzano, F., Bernardi, G., et al. (2009). Selective CB2 receptor agonism protects central neurons from remote axotomy-induced apoptosis through the PI3K/Akt pathway. J. Neurosci. 29, 4564-4570. doi: 10.1523/JNEUROSCI.078609.2009

Walsh, D. M., and Selkoe, D. J. (2004). Deciphering the molecular basis of memory failure in Alzheimer's disease. Neuron 44, 181-193. doi: 10.1016/j.neuron.2004.09.010

White, J. A., Manelli, A. M., Holmberg, K. H., Van Eldik, L. J., and Ladu, M. J. (2005). Differential effects of oligomeric and fibrillar amyloid-beta 1-42 on astrocyte-mediated inflammation. Neurobiol. Dis. 18, 459-465. doi: $10.1016 /$ j.nbd.2004.12.013

Wotherspoon, G., Fox, A., McIntyre, P., Colley, S., Bevan, S., and Winter, J. (2005). Peripheral nerve injury induces cannabinoid receptor 2 protein expression in rat sensory neurons. Neuroscience 135, 235-245. doi: 10.1016/j.neuroscience.2005.06.009

Yiangou, Y., Facer, P., Durrenberger, P., Chessell, I. P., Naylor, A., Bountra, C., et al. (2006). COX-2, CB2 and P2X7-immunoreactivities are increased in activated microglial cells/macrophages of multiple sclerosis and amyotrophic lateral sclerosis spinal cord. BMC Neurol. 6:12. doi: 10.1186/1471-2377-6-12

Zarranz, J. J., Alegre, J., Gómez-Esteban, J. C., Lezcano, E., Ros, R., Ampuero, I., et al. (2004). The new mutation, E46K, of alpha-synuclein causes Parkinson and Lewy body dementia. Ann. Neurol. 55, 164-173. doi: 10.1002/ana.10795

Zhang, J., Hoffert, C., Vu, H. K., Groblewski, T., Ahmad, S., and O'Donnell, D. (2003). Induction of CB2 receptor expression in the rat spinal cord of neuropathic but not inflammatory chronic pain models. Eur. J. Neurosci. 17, 2750-2754. doi: 10.1046/j.1460-9568.2003.02704.x

Zhang, W., Wang, T., Pei, Z., Miller, D. S., Wu, X., Block, M. L., et al. (2005). Aggregated alpha-synuclein activates microglia: a process leading to disease progression in Parkinson's disease. FASEB J. 19, 533-542. doi: 10.1096/fj.04-2751com

Conflict of Interest Statement: The authors declare that the research was conducted in the absence of any commercial or financial relationships that could be construed as a potential conflict of interest.

Copyright (C) 2017 Cassano, Calcagnini, Pace, De Marco, Romano and Gaetani. This is an open-access article distributed under the terms of the Creative Commons Attribution License (CC BY). The use, distribution or reproduction in other forums is permitted, provided the original author(s) or licensor are credited and that the original publication in this journal is cited, in accordance with accepted academic practice. No use, distribution or reproduction is permitted which does not comply with these terms. 